\title{
Chinese CEO, Risk Taking and the Power of CEO: Empirical Evidence from Malaysian Family Firms
}

\author{
Swee-Sim Foong \\ Universiti Sains Malaysia \\ Jiunn-Shyan Khong ${ }^{b}$ \\ Universiti Sains Malaysia \\ Boon-Leong Lim ${ }^{\mathrm{c}}$ \\ Tunku Abdul Rahman University College
}

\begin{abstract}
This paper examines the risk taking behaviour of Chinese CEO. Our analysis is based on a sample of 362 family firms in Malaysia over the 2009-2015 period using panel GMM methodology. Firstly, our results offer evidence that Chinese CEOs are risk taking. We then examine how CEO power, in the context of Finkelstein's (1992) structural power, ownership power, expert power and prestige power, might drive risk taking of Chinese CEOs. The results are rather mixed where greater ownership power is likely to promote higher risk taking but greater expert power resulted in lower risk taking. We further show that corporate governance can mitigate risk taking of Chinese CEO in family firms. When the proportions of independent directors and foreign institutional shareholdings exceed the median thresholds of $40 \%$ and $5 \%$, respectively, we find that CEO risk taking behaviour turns from positive to negative. Stronger evidence is found when we adjust the thresholds to the 75 th percentile of $50 \%$ and $15 \%$, respectively. The result is also robust with the use of leverage as a measure for CEO risk taking.
\end{abstract}

Keywords: CEO power, Chinese CEO, corporate governance, risk taking JEL classification: G32, G34

\section{Introduction}

Family-owned businesses play a critical role in the Malaysian economy. Family-owned firms represent a full spectrum of Malaysian companies from father-son partnerships to multinational corporations and conglomerates. According to some early studies, more

a Management Section, School of Distance Education, Universiti Sains Malaysia, 11800 USM, Pulau Pinang, Malaysia. Email: foongss@usm.my (Corresponding author)

b School of Management, Universiti Sains Malaysia, Jalan Sasaran, 11800 Gelugor, Pulau Pinang, Malaysia. Email: daviskhongjiunnshyan@student.usm.my; daviskhongjiunnshyan@hotmail.com

c Department of Accountancy and Business, Penang Branch Campus, Tunku Abdul Rahman University College, 11200 Tanjung Bungah, Pulau Pinang, Malaysia. Email: Iboonl933@gmail.com

\section{Acknowledgments}

The authors acknowledge financial support of Universiti Sains Malaysia (USM) Research University Grant (1001/PJJAUH/816292). The usual disclaimer applies.

Article Info: Received 7 October 2020; Revised 31 December 2020; Accepted 2 March 2021 https://doi.org/10.22452/MJES.vol58no1.4 
than $70 \%$ of Malaysian businesses are family owned (Claessens et al., 2000). Some previous studies even show that around $45 \%$ of listed companies in Malaysia are family firms (Abdul Samad et al., 2008; Carney \& Child, 2013) and they contributed about 67\% of the GDP (Fan et al., 2011).

Family firms, in general, have better financial performance, in terms of better equity prices, higher business revenue, profitability and growth as they emphasise on investment and R\&D, but they tend to be more conservative or are less geared in balance sheet (Credit Suisse, 2018). It is well documented that the performance of family firms is more or less related to their financial management style, but little is known about the non-financial aspects that drive the success of family firms, especially the kind of cultural values and norms that they adopted. In this context, we are interested to know the characteristics of family firms that take more risk that leads to their greater firm performance.

An interesting fact about Malaysian family firms is that many of them are owned by local ethnic Chinese, and most of them have a long establishment history, with some existing even before the independence of the nation. The local Chinese has managed to pass the firm's management from father to son, and some businesses have passed down to the 3rd or 4th generation. Their business capital and networks are accumulated in the family and their scope of businesses are usually highly diversified. Some businesses have grown to be successful conglomerates such as Berjaya, Genting, Hap Seng and YTL. This shows that Malaysian Chinese family firms are willing to take the risk to venture out into new territories. Expanding business and venturing into new businesses require higher leverage, greater capital expenditure and probably resulting in lower cash flow. Such risk taking mentality is likely to be cultivated by the culture and values of the local ethnic Chinese, which is slightly different from the Chinese in mainland China. The local Chinese in Malaysia, and other parts of the Southeast Asia countries, are predominately known as the overseas Chinese or "Huaqiao". ${ }^{1}$ These Chinese diasporas may have been far away from their ancestral country, mainland China, in terms of both time and space, but as the 2 nd or 3rd generations (some may still be the first generation migrants) in Malaysia, their adventurist spirit is still reflected in their business risk taking profile. These overseas Chinese have dominated a huge business network in Southeast Asian countries (Chen, 2001; Yeung, 1996). It is believed that they have controlled over $70 \%$ of the corporate wealth in the region (Backman, 1995). So, what is unique about Chinese family firms in Malaysia?

This paper intends to shed light on this issue by examining whether listed firms run by Chinese CEO are taking higher risk. We are motivated to investigate Chinese CEO managerial risk taking for three reasons. First, there is no empirical insight addressing the managerial risk taking behaviour of Chinese CEO despite their relatively successful

\footnotetext{
Huaqiao is not the only group of ethnic Chinese in Malaysia and other parts of the Southeast Asian region. There are earlier Chinese migration, as early as 13th century up to the 17th century, with a majority of these early groups assimilating with the local indigenous people which later form a subgroup called the Peranakan in Malaysia and Singapore. The huge migration of Huaqiao to Southeast Asia happened in the 18th and 19th century during the colonial era, especially to cushion the development of the mining sectors in Malaysia.
} 
path in the corporate landscape. Second, recent literature points out that managerial risk taking is due to CEO power. Thus, we wish to investigate further if Chinese CEO exploit their executive and non-executive power in assuming managerial risk taking. Finally, it would be of interest to examine if Chinese CEO managerial risk taking behaviour is mitigated by corporate governance mechanism, i.e. both internal and external monitoring forces.

The contribution of this paper is twofold. First, to the best of our knowledge, there is no study on risk taking behaviour of overseas Chinese CEO, except for the studies on Chinese CEO in China mainland, like Li and Tang (2010) and recently Zhang and Fu (2020). Therefore, this study may be the first to venture into empirical finance on CEO of overseas Chinese ethnicity. The few empirical research on Chinese managers predominantly focuses on mainland China or neighbouring Sino countries like Taiwan and Hong Kong. However, the Chinese in these studies have slightly different behaviour from overseas Chinese in the rest of the world. Only a few empirical studies are on overseas Chinese business orientation, such as Chuah et al. (2016) on Malaysian Chinese's capitalism and recently Rodríguez-Gutiérrez et al. (2020) on Spanish Chinese immigrants' business risk taking propensities through networking effect. Ethnicity and finance are a rarely investigated area, especially in a multiracial country like Malaysia, as it has the potential to be regarded as a sensitive issue. However, when finance research drill in depth into personal traits of a manager who makes all the strategic and financial decision, we have to deal with the whole person scientifically to understand how the manager may be affected by culture (finance and ethnicity), personal beliefs (finance and religion) and biological nature (finance and gender) in his/her decision making.

Second, this paper illustrates a good comparative study on overseas Chinese. A study on the Malaysian Chinese is a natural sample for a comparative study because the Chinese remain the second largest ethnic group comprising nearly $25 \%$ of the population, after the Malays and indigenous residents who make up nearly $70 \%$ of the population. In fact, Malaysia has the third largest number of overseas Chinese in Southeast Asia after Indonesia and Thailand (Statista, 2018). Such comparative study is not possible for overseas Chinese in other countries in the rest of the world where the percentage of Chinese population is relatively small. Even for Indonesia and Thailand, a comparative study is highly challenging, if not impossible. The challenge lies in the task of identifying a local Chinese from a formal source of public information. The Chinese in both countries were assimilated into local society in the 1960s and 1920s, respectively, to the extent of not allowing them to have their Chinese name, Chinese education system and speaking Mandarin, celebrating Chinese traditional festivals and lifestyles. Hence, only a handful of their Chinese corporate leaders might still retain their cultural identity of Chinese and the Confusion mind set. Malaysia and Singapore do not experience such assimilation process. But, while the education system in Malaysia allows for Chinese national-type primary schools and independent Chinese high schools, the Singapore government has turned their education system into Englishbased. Therefore, the Malaysian Chinese community provides a better representation of overseas Chinese than those living in other countries in Southeast Asia. Moreover, Singapore does not have a sufficient number of non-Chinese managers in corporations. Therefore, Singapore is not suitable as a choice for comparative study. 
The rest of this paper is organised as follows. Section 2 presents our hypotheses development. Section 3 reports the methodology and data, sampling firms and regression models. Section 4 presents the results and findings discussion. Lastly, we draw out some policy implications in Section 5 as a conclusion.

\section{Hypothesis Development}

\subsection{Chinese CEO and Managerial Risk Taking in Family Firms}

In the context of agency theory, the conflict between management and shareholders is a result of different preference in risk taking. On one hand, for job security, a manager (CEO) would prefer to take less risk if his compensation is highly tied with firm performance. On the other hand, shareholders in accordance with the high risk high return principle, would prefer a firm to assume certain level of risk to obtain the highest possible returns. Thus, managerial risk taking can become an agency issue.

In family firms, however, the issue is even more complex, as risk taking may be related to the status of the manager as family CEO. If the manager is the founder CEO, the risk taking can be nonlinearly related to the age of the founder. As recently documented in Yeoh and Hooy (2020), a founder may take high risk in his/her early career and reduce risk taking in the successive stage. Nevertheless, towards the retiring period, his/her risk taking may rise again in an attempt to create a greater business empire for his/her successor. On the contrary, if the CEO is the second or third generation family member, empirical evidence show that they might be less willing to take risk. In the case of a family CEO, agency issue is slightly different because since the family member is mostly one of the large shareholders, the normal agency conflict, namely Type I agency conflict, is not applicable. Instead, we expect Type II agency conflict, i.e. between large shareholders and minority shareholders where large shareholders running as top management, may set policies that exploit the welfare of the minority shareholders. So a family CEO may take relatively higher risk with type II agency behaviour to exploit the minority shareholders as they can always expropriate the abnormal returns and distribute the abnormal losses with minority shareholders. Thus, if the Chinese CEO in the family firm is a family CEO, he or she may take relatively higher risk. ${ }^{2}$

Our deduction that Chinese CEO are high risk takers is also based on empirical basis. According to the cultural scores of Hofstede (2001), uncertainty avoidance (an inverse measure of risk taking) score of Singapore is the lowest in the world. In other words, Singapore, a nation with the most number of Huaqiao Chinese (more than $75 \%$ of the population), has the highest risk taking attitude in the world. Other Chinese based countries that are also in the top 10 risk taking (top 10 lowest uncertainty

2 We thank the reviewer for pointing out this issue. Our paper focuses on Chinese CEO and not Chinese family CEO. We do not have data on the identity of family CEO. We expect most of the Chinese CEO in family firms are family CEO. Since we cannot provide a formal test to differentiate Chinese family CEO from Chinese non-family CEO, we can at best deduce that if a Chinese CEO in the family firm have relatively higher risk taking behaviour, they are likely to be Chinese family CEO. 
avoidance scores), include Hong Kong (4th spot), China (6th spot), and Malaysia (10th spot). Malaysia, with its Chinese population of nearly $25 \%$ of the country's population is ranked lower due to the much lower proportion of Huaqiao than that of Singapore's. In fact, both Malaysian Chinese and Singapore Chinese shared the same roots from Southern China and both nations were British colonies just slightly more than half a century ago, sharing a multi-cultural society with a mixture of eastern and western values. The two nations were once the same country from 1963 to 1965, and they share a border and is connected geographically. Most Singaporeans are Malaysian Chinese that have migrated since the 1980s when Singapore developed as a highincome nation. In a nutshell, the Chinese CEO in Malaysian family firms are mostly the high risk taking Huaqiao.

Our deduction is also supported by a recent study of Rodríguez-Gutiérrez et al. (2020). They found that the first-generation Chinese immigrants in Spain (like the founder CEO in our sample) who have better networking or so-called "guanxi" has higher risk taking profile relative to other ethnicity. Their survey on Chinese immigrants in Andalusia (Spain) shows that the risk taking propensity of immigrant-owned businesses increases over time starting from the immigrant entrepreneurs' arrival while the education level of Chinese entrepreneurs has no impact on their risk taking propensity. As a result, ceteris paribus, our first hypothesis is:

$\mathrm{H}_{1}$ : Family firms with Chinese CEO have higher managerial risk taking likelihood

\subsection{The Power of CEO and Managerial Risk Taking in Family Firms}

Earlier literature like Pathan (2009) shows that CEO that hold more power are less willing to take risk. However, recent studies, especially on banks sampled from the subprime crisis like Lewellyn and Muller-Kahle (2012) and Ho et al. (2016), show that CEO power often comes hand in hand with optimism and overconfidence. Hence, the likelihood of risk engagement is higher. The positive relationship between CEO power and risk taking is presented in other literature like Chintrakarn et al. (2015) and Sheikh (2019), while a negative outcome is presented in Haider and Fang (2018) using total risk and idiosyncratic risk as risk proxies. This paper measures CEO power in four dimensions, as defined by Finkelstein (1992). First is the structural power which measures the power that comes from the CEO's legitimate formal position within the organisation. Second is the ownership power which is the power derived from shareholdings of the CEO. Third is the expert power which refers to the CEO's personal ability that comes from his/her educational background and professional training; we proxy the result of expertise as having foreign working experience since foreign employment captures a higher degree of professionalism possessed by the CEO. Fourth and last, the prestige power which comes from the CEO's personal background that helps him/her to earn privileged treatment or respect from the organisation, for instance, status as the founder, descendent, or family member of the founder or major owner. In this context, we focus on structural power which covers CEO duality in deciding the board decision, ownership power which can be measured by CEO shareholdings, expert power measured by the foreign working experience of the CEO, 
and finally the prestige power measured by the status of founder CEO. The general hypothesis to be tested is spelled out as $\mathrm{H}_{2}$ below:

$\mathrm{H}_{2}$ : The more power a Chinese CEO holds, the higher is the managerial risk taking likelihood

To examine the effect of the individual dimensions, we specifically test the following four sources of CEO power accordingly:

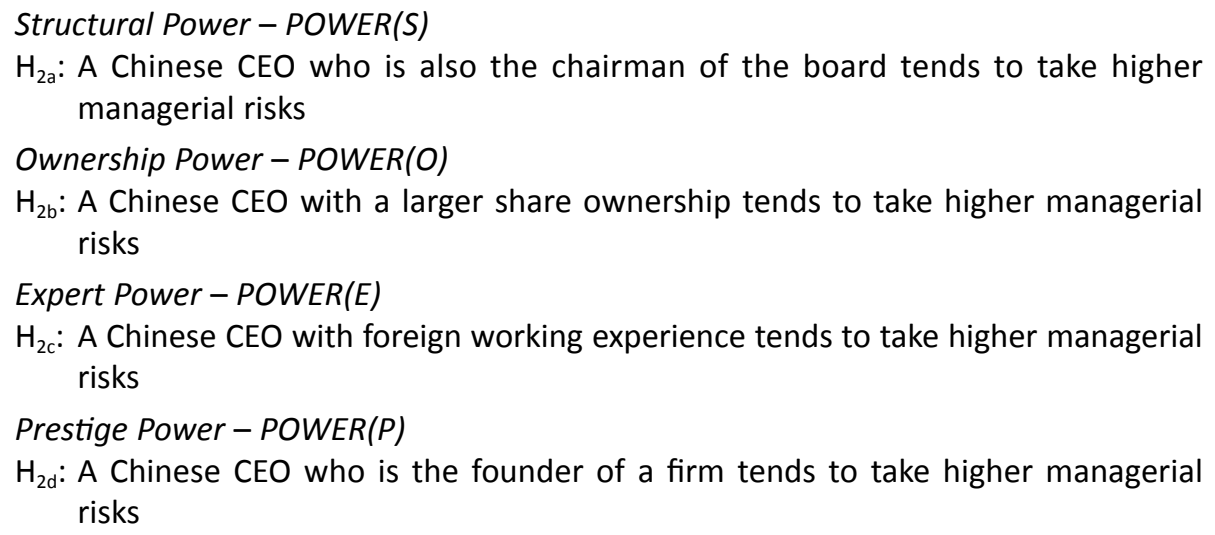

Structural power and ownership power are basically executive powers where more of these powers means the CEO has more executive rights in corporate decision making whereas expert power and prestige power are non-executive powers as the CEO would not have any formal rights in decision making even though they have the expertise or are the founders of the firms.

\subsection{Internal (Independent Directors) Monitoring and Risk Taking}

The presence of family members in family firms may increase the tendency of expropriation of minority shareholder interests, or so-called Type II agency conflicts (Shleifer \& Vishny, 1997; Villalonga \& Amit, 2006) between controlling family shareholders and minority shareholders in family firms. Although the Chinese CEO may have certain executive or non-executive power in promoting higher will in managerial risk taking, a strong corporate mechanism may prevent any abuse of power and balance the managerial risk taking appetite. While family ownership is associated with possible managerial entrenchment (Gomez-Mejia et al., 2001), independent directors play a critical role to prevent bias judgment and their presence in the board may enhance the vigilance to protect the shareholder's interests (Rosenstein \& Wyatt, 1990). Independent directors are an internal control mechanism to scrutinize agency exploitation especially on executive compensation (Daily et al., 1998). So, when a firm have higher proportion of independent directors, it can limit exploitation of managerial power and misuse of firm's resources. With poor corporate governance culture in emerging markets, the strength of independency in the boardroom is going to deliver a strong internal monitoring on CEO action. Hence, the following hypothesis is suggested: 
$\mathrm{H}_{3}$ : When a firm has stronger internal monitoring, the Chinese CEO managerial risk taking could be mitigated

\subsection{External (Institutional) Monitoring and Risk Taking}

Besides internal control through the appointment of independent directors, other shareholders may also play an active role in enforcing external monitoring. Such ownership monitoring usually relies on institutional shareholders, especially foreign institutions which are more active and engaging in governing their investment subject. Most institutional monitoring literature however, focuses on executive compensation (Almazan et al., 2005; Janakiraman et al., 2010; Zheng, 2010) and firm performance (Elyasiani \& Jia, 2008) but lack in other aspects of corporate governance. Empirical evidence documented that institutional shareholder activism may enhance firm's performance and profitability (Dimson et al., 2015), but Stapledon (1996) has earlier on argued that institutional investors might not have the incentive to monitor but prefer to vote to exit instead, especially those funds that delegate their investment functions to external managers (Del Guercio \& Hawkins, 1999). In fact, a recent study by Tee et al. (2018) revealed that local institutional investors do not portray effective monitoring on Malaysian executive compensation, but foreign institutional investors are associated with better monitoring. This is understandable as foreign institutional shareholders are mostly sophisticated investors, so they possess resources to gather relevant information for monitoring purposes at marginal cost. Thus, we deduce that:

$\mathrm{H}_{4}$ : When a firm has stronger external monitoring, the Chinese CEO managerial risk taking could be mitigated

\section{Data and Methodology}

According to Mazur and Wu (2016), family firms could be identified based on the family affiliation of board of directors and the CEO. In addition, the study by Villalonga and Amit (2006) and Anderson and Reeb (2003) indicated that a firm would be deemed as under family control if: (i) the founder or any family member of the founder sits on the board and/or is a substantial shareholder, and (2) two or more board members are having family relationship. Thus, following the criteria demonstrated in past research, this study identified family firms from all public firms listed on the Main Board of Bursa Malaysia during the period of 2009 to 2015. The final sample of this study consists of 362 listed Malaysian family firms mainly from five sectors, including industrial products, properties, construction, consumer products, and trading and services.

This study employed a common measure of risk taking, which is, capital expenditures or CAPEX. There are many studies that utilise capital expenditures as the proxy for managerial risk taking. Both Cho and Kim (2017) and Cheng (2004) alleged that the CEO has a great influence on risky strategies through capital expenditures. Other similar research such as Bhagat and Welch (1995), Harjoto et al. (2018), and Hoskisson et al. (2017) also identified capital expenditures as a measure of risk taking. Following Coles et al. (2006), capital expenditure is computed as capital expenditure divided by book value of assets. To prevent confounding effects, this study incorporates several control 
variables such as firm size (SIZE) proxied by total assets, firm value (VALUE) proxied by Tobin's $Q$, year of firm incorporation also known as firm age (AGE), firm performance (PERFORMANCE) proxied by return on assets, and firm growth (GROWTH) proxied by the net sales of firm on current year minus the net sales of firm on previous year divided by the net sales of firm on previous year. All the variables are downloaded from Thomson Reuters DataStream.

To identify a Chinese CEO, we use a dummy variable verified manually from the CEO profile in annual reports. The dummy takes the value of 1 if the CEO is a Malaysian Chinese, and zero otherwise. Overall, $83.5 \%$ of the family firms are led by Malaysian Chinese CEOs; while non-Chinese CEOs only constituted $16.5 \%$.

The panel model approach is used for analysis. The panel model in our case is likely to suffer from endogeneity issue (e.g. past risk taking influences the current risk taking and/or potential endogeneity caused by reverse causality within the models). A dynamic generalized method of moments (GMM) estimator is employed with 1-year lag effect of risk taking $\left(\mathrm{RISK}_{\mathrm{t}-1}\right)$ incorporated as one of the independent variables in the models and with appropriate instrumental variables incorporated in the estimation. The time dimension of our panel data set is only six years $(T=6)$ but with a sufficient number of firms $(\mathrm{N}=362)$. Hence, our overall sample is considered a small panel data set which may lead to estimation bias and inefficiency. As a result, compared with other panel and GMM estimators, system GMM is selected as it can address small sample bias and deliver more precise results (Soto, 2009). Also, system GMM is capable of solving unobserved firm fixed effect and has enhance estimator over difference GMM in addressing the joint endogeneity problem of all the regressors (Wintoki et al., 2012).

To examine $\mathrm{H}_{1}$, i.e. whether Malaysian Chinese CEOs have higher risk taking appetite, the following model in GMM setting is estimated:

$$
\begin{aligned}
\text { RISK }= & \beta_{0}+\beta_{1} \text { RISK }_{\mathrm{t}-1}+\beta_{2} \text { SIZE }+\beta_{3} \text { VALUE }+\beta_{4} \text { AGE }+\beta_{5} \text { GROWTH }+ \\
& \beta_{6} \text { PERFORMANCE }+\beta_{7} D_{\text {chinese }}+\text { Year }+ \text { Sector }+\varepsilon
\end{aligned}
$$

In Model (1), the dependent variable RISK denotes risk taking, and is measured by CAPEX. The control variables include SIZE, VALUE, AGE, GROWTH and PERFORMANCE. $D_{\text {chinese }}$ is a dummy variable taking the value of 1 if the CEO is a Malaysian Chinese. This study also controls for Year and Sector effects, and $\varepsilon$ is the error term.

Next, to address the list of four hypotheses from $\mathrm{H}_{2 a}$ to $\mathrm{H}_{2 \mathrm{~d}}$ on whether the power of CEO would influence risk taking, the following model is estimated:

$$
\begin{aligned}
\text { RISK }= & \beta_{0}+\beta_{1} \text { RISK }_{\mathrm{t}-1}+\beta_{2} \text { SIZE }+\beta_{3} \text { VALUE }+\beta_{4} \text { AGE }+\beta_{5} \text { GROWTH }+\beta_{6} \text { PERFORMANCE }+ \\
& \beta_{7} D_{\text {chinese }}+\beta_{8} \text { POWER }+\beta_{9}\left(D_{\text {chinese }} \times \text { POWER }\right)+\text { Year }+ \text { Sector }+\varepsilon
\end{aligned}
$$

In Model (2), this study interacts the dummy variable of Malaysian Chinese CEO $\left(D_{\text {Chinese }}\right)$ with the four power proxies, i.e. CEO duality (POWER-S) to represent structural power, CEO share ownership (POWER-O) to represent ownership power, CEO foreign working experience (POWER-E) to represent expert power, and CEO as the founder (POWER-P) to represent prestige power. Similar to the ethnicity of CEO, the proxies for the interaction variables in Model (2) are all hand collected from the annual reports under the section of CEO profile.

The description of the measurement of the main variables and control variables of this study is summarised in Table 1. 
Table 1. Variable description

\begin{tabular}{|c|c|c|c|}
\hline Variable & Description & $\begin{array}{l}\text { Unit of } \\
\text { measure }\end{array}$ & Source \\
\hline \multicolumn{4}{|l|}{ Dependent variable } \\
\hline Risk taking (RISK) & $\begin{array}{l}\text { Measured by the ratio of capital } \\
\text { expenditure of firms with the formula } \\
\text { of capital expenditure divided by book } \\
\text { value of assets. }\end{array}$ & Ratio & $\begin{array}{l}\text { Thomson Reuters } \\
\text { DataStream }\end{array}$ \\
\hline \multicolumn{4}{|c|}{ Independent variable } \\
\hline$D_{\text {Chinese }}$ & $\begin{array}{l}\text { Dummy variable taking a value of } 1 \text { if } \\
\text { the CEO is Malaysian Chinese, and } \\
\text { zero otherwise. }\end{array}$ & N/A & Annual report \\
\hline $\begin{array}{l}\text { Structural power } \\
\text { (POWER-S) }\end{array}$ & $\begin{array}{l}\text { Dummy variable taking a value of } 1 \text { if } \\
\text { the CEO is the chairman of the firm, } \\
\text { and zero otherwise. }\end{array}$ & N/A & Annual report \\
\hline $\begin{array}{l}\text { Ownership power } \\
\text { (POWER-O) }\end{array}$ & $\begin{array}{l}\text { Proxied by the ratio of share ownership } \\
\text { of CEO in firms }\end{array}$ & Ratio & Annual report \\
\hline $\begin{array}{l}\text { Expert power } \\
\text { (POWER-E) }\end{array}$ & $\begin{array}{l}\text { Dummy variable taking a value of } 1 \text { if } \\
\text { the CEO has foreign working experience, } \\
\text { and zero otherwise. }\end{array}$ & N/A & Annual report \\
\hline $\begin{array}{l}\text { Prestige power } \\
\text { (POWER-P) }\end{array}$ & $\begin{array}{l}\text { Dummy variable taking a value of } 1 \text { if } \\
\text { the CEO is the founder of the firm, and } \\
\text { zero otherwise. }\end{array}$ & $\mathrm{N} / \mathrm{A}$ & Annual report \\
\hline \multicolumn{4}{|l|}{ Control variables } \\
\hline Firm size (SIZE) & $\begin{array}{l}\text { Proxied by natural logarithm of firm's } \\
\text { total assets. }\end{array}$ & Ratio & $\begin{array}{l}\text { Thomson Reuters } \\
\text { DataStream }\end{array}$ \\
\hline $\begin{array}{l}\text { Firm value } \\
\text { (TOBINQ) }\end{array}$ & $\begin{array}{l}\text { Proxied by firm's Tobin's Q with the } \\
\text { formula of firm's market value of all } \\
\text { outstanding shares and the firm's } \\
\text { debts divided by book value of firm's } \\
\text { total assets. }\end{array}$ & Ratio & $\begin{array}{l}\text { Thomson Reuters } \\
\text { DataStream }\end{array}$ \\
\hline Firm age (AGE) & $\begin{array}{l}\text { Measured by firm's total year of } \\
\text { incorporation. }\end{array}$ & Years & $\begin{array}{l}\text { Thomson Reuters } \\
\text { DataStream }\end{array}$ \\
\hline $\begin{array}{l}\text { Firm performance } \\
\text { (PERFORMANCE) }\end{array}$ & $\begin{array}{l}\text { Proxied by return on assets of firms } \\
\text { with the formula of net income divided } \\
\text { by total assets. }\end{array}$ & Ratio & $\begin{array}{l}\text { Thomson Reuters } \\
\text { DataStream }\end{array}$ \\
\hline $\begin{array}{l}\text { Firm growth } \\
\text { (GROWTH) }\end{array}$ & $\begin{array}{l}\text { Proxied by the sales growth of firms } \\
\text { with the formula of net sales of firm on } \\
\text { current year minus the net sales of firm } \\
\text { on previous year divided by the net sales } \\
\text { of firm on previous year. }\end{array}$ & Ratio & $\begin{array}{l}\text { Thomson Reuters } \\
\text { DataStream }\end{array}$ \\
\hline
\end{tabular}


Table 2 presents the descriptive statistics. Based on Table 2, we can see that RISK proxied by CAPEX of family firms in Malaysia has an average value of 0.037 , while the mean value for $\mathrm{D}_{\text {chinese }}$ of $83.5 \%$ indicates that Malaysian Chinese CEO is dominating family firms. With respect to the CEO power, the first proxy, CEO duality (POWER-S), shows that in average only about $16 \%$ of CEOs are chairing the board. However, the second power measure, POWER-O, indicates CEO shareholdeings is $26 \%$ in Malaysian family firms on average, which is quite high. This implies that even though CEOs in family firms do not chair the board, they still have great extent of power to influence the decision making of the company's policies. The third measure of CEO power, POWER-E, shows that on average, $23.6 \%$ of CEOs have foreign working experience, whereas the fourth measure, POWER-P, shows that around $27 \%$ of CEOs are founders of the firms.

To test $\mathrm{H}_{3}$ and $\mathrm{H}_{4}$, we refer to the distribution of the ratios of independent directors and foreign institutional shareholdings. Based on Table 2, the median (50 percentiles) value for both ratios are 0.4286 and 0.0472 , respectively. So, we estimate Model (2) based on this threshold by rounding the value to $40 \%$ and $5 \%$, respectively. For robustness test, we use the value of 75th percentiles as the threshold of the respective criteria, pushing the proportions up to $50 \%$ and $15 \%$, respectively.

Table 2. Descriptive statistics

\begin{tabular}{|c|c|c|c|c|c|c|c|c|}
\hline Variable & Obs. & Mean & Std. dev. & Min & Max & P25 & Median & P75 \\
\hline \multicolumn{9}{|l|}{ Dependent variables } \\
\hline RISK & 2534 & 0.037 & 0.044 & 0 & 0.529 & 0.008 & 0.023 & 0.050 \\
\hline \multicolumn{9}{|l|}{ Independent variable } \\
\hline$D_{\text {Chinese }}$ & 2534 & 0.835 & 0.371 & 0 & 1 & 1 & 1 & 1 \\
\hline \multicolumn{9}{|l|}{ Control variables } \\
\hline SIZE & 2534 & 12.741 & 1.231 & 10.092 & 18.305 & 11.893 & 12.602 & 13.396 \\
\hline TOBINQ & 2533 & 0.957 & 0.574 & 0.227 & 7.869 & 0.679 & 0.821 & 1.038 \\
\hline AGE & 2533 & 23.156 & 14.646 & 2 & 95 & 13 & 18 & 32 \\
\hline GROWTH & 2533 & 0.114 & 0.792 & -0.967 & 22.687 & -0.076 & 0.041 & 0.163 \\
\hline PERFORMANCE & 2534 & 0.048 & 0.080 & -0.708 & 2.122 & 0.017 & 0.046 & 0.079 \\
\hline \multicolumn{9}{|l|}{ Interacting variables } \\
\hline $\operatorname{POWER}(S)$ & 2534 & 0.158 & 0.365 & 0 & 1 & 0 & 0 & 0 \\
\hline POWER(O) & 2534 & 0.260 & 0.213 & 0 & 0.842 & 0.021 & 0.260 & 0.440 \\
\hline POWER(E) & 2534 & 0.236 & 0.425 & 0 & 1 & 0 & 0 & 1 \\
\hline POWER(P) & 2534 & 0.272 & 0.445 & 0 & 1 & 0 & 0 & 1 \\
\hline \multicolumn{9}{|l|}{ Subsample criteria } \\
\hline $\begin{array}{l}\text { Independent } \\
\text { directors }\end{array}$ & & & & 0.0909 & 0.8750 & 0.3750 & 0.4286 & 0.5000 \\
\hline $\begin{array}{l}\text { Foreign institutional } \\
\text { ownership }\end{array}$ & & & & 0.0003 & 0.8053 & 0.0139 & 0.0472 & 0.1405 \\
\hline
\end{tabular}

Note: $\mathrm{P} 25$ and $\mathrm{P} 75$ represent the 25 th and 75 th percentile, respectively. 
The pairwise correlation result shows that the magnitude of correlation among all variables are generally low. The highest is between RISK and SIZE with a value of 0.4446 showing that the bigger the firm size the higher the risk taking in family firms. To conserve space, we do not report the correlation result here, but it is available upon request.

\section{Results and Analysis}

\subsection{Effect of Malaysian Chinese CEO and CEO Power on Risk Taking}

Table 3 reports the GMM panel regression estimates with baseline and interaction models with year and sector effects to control for unobserved time and sector heterogeneity. The $A R(1)$ tests are statistically significant which indicate that the estimates generated from the system GMM are acceptable and the AR(2) tests confirm that there are no second order serial correlations or higher orders in our sample data, and most importantly, the Hansen tests of instrument validity show that the instrument variables used in our models to determine the endogeneous variables are appropriate and valid. These diagnostic tests are all similar from Table 3 to Table 5. The lagged risk taking $\left(\mathrm{RISK}_{\mathrm{t}-1}\right)$ is also statistically significant in all the models. This suggests that risk taking is highly persistent and requires time to adjust to its long-run equilibrium. This is in line with the conjecture of Adhikari and Agrawal (2016) that riskier policies tend to be persistently adopted due to the persistent risk culture or business models.

All control variables are statistically significant in all three tables explaining risk taking, with consistent signs and magnitude of coefficients across the baseline and interaction models. This suggests that family firms with better performance, greater firm value, higher sales growth and that are bigger in size tend to take more risk, while firm age is the only control variable having a negative sign, implying that family firms with longer existence are less likely to take risks.

The dummy $D_{\text {chinese }}$ is found to be positive and statistically significant for all models in Table 3, including the baseline and interaction models. This signifies that Malaysian Chinese CEOs tend to take higher risk than non-Malaysian Chinese CEOs regardless of the power they possess, showing strong support for $\mathrm{H}_{1}$. On the interaction results of the four powers, only CEO share ownership has significant positive interaction effects, whereas CEO foreign working experience shows a negative sign and significant interaction effect. In regard to the magnitude of coefficient, the interaction $D_{\text {chinese }} x$ POWER-O has a bigger magnitude $(0.0593)$ but lower significance level $(p<0.05)$ as compared to the dummy coefficient without any interaction of power $(0.0361, p<0.01)$, while the magnitude of the coefficient of the interaction $D_{\text {chinese }} \times$ POWER-E has a smaller magnitude (0.0258) but with a negative sign.

The result implies that with greater ownership power, Chinese CEOs are likely to take higher risk. This finding is consistent with Type II agency conflicts implying either most Chinese in family firms adhere to the controling family shareholders (so they are given more shares as compensation) or they are likely family CEOs themselves and assume excessive risk. Another explanation is, with high ownership power, the CEO gains greater confidence and is optimistic in engaging higher risk taking projects, 
Table 3. GMM estimations of risk taking and CEO powers

\begin{tabular}{|c|c|c|c|c|c|}
\hline \multirow{2}{*}{$\begin{array}{l}\text { Dependent variable: } \\
\text { RISK (Risk taking) }\end{array}$} & \multirow{2}{*}{ Baseline } & \multicolumn{4}{|c|}{ CEO power } \\
\hline & & POWER(S) & POWER(O) & POWER(E) & POWER(P) \\
\hline Lag(RISK) & $\begin{array}{l}0.2119 * * * \\
(0.0131)\end{array}$ & $\begin{array}{l}0.2036^{* * *} \\
(0.0137)\end{array}$ & $\begin{array}{l}0.2149 * * * \\
(0.0132)\end{array}$ & $\begin{array}{l}0.2107^{* * *} \\
(0.0130)\end{array}$ & $\begin{array}{l}0.2135^{* * *} \\
(0.0133)\end{array}$ \\
\hline $\mathrm{D}_{\text {chinese }}$ & $\begin{array}{l}0.0361 * * * \\
(0.0066)\end{array}$ & $\begin{array}{l}0.0338^{* * *} \\
(0.0078)\end{array}$ & $\begin{array}{l}0.0239 * * * \\
(0.0092)\end{array}$ & $\begin{array}{l}0.0365^{* * *} \\
(0.0078)\end{array}$ & $\begin{array}{l}0.0368^{* * *} \\
(0.0066)\end{array}$ \\
\hline PERFORMANCE & $\begin{array}{l}0.0188^{* *} \\
(0.0080)\end{array}$ & $\begin{array}{r}0.0155^{*} \\
(0.0089)\end{array}$ & $\begin{array}{l}0.0209 * * \\
(0.0086)\end{array}$ & $\begin{array}{l}0.0242^{* *} \\
(0.0095)\end{array}$ & $\begin{array}{l}0.0211^{* *} \\
(0.0084)\end{array}$ \\
\hline SIZE & $\begin{array}{l}0.0035^{* * *} \\
(0.0010)\end{array}$ & $\begin{array}{l}0.0038^{* * *} \\
(0.0011)\end{array}$ & $\begin{array}{l}0.0035^{* * *} \\
(0.0010)\end{array}$ & $\begin{array}{l}0.0032^{* * *} \\
(0.0010)\end{array}$ & $\begin{array}{l}0.0033^{* * *} \\
(0.0010)\end{array}$ \\
\hline VALUE & $\begin{array}{l}0.0115^{* * *} \\
(0.0015)\end{array}$ & $\begin{array}{l}0.0125^{* * *} \\
(0.0015)\end{array}$ & $\begin{array}{l}0.0111 * * * \\
(0.0015)\end{array}$ & $\begin{array}{l}0.0118^{* * *} \\
(0.0015)\end{array}$ & $\begin{array}{l}0.0108^{* * *} \\
(0.0015)\end{array}$ \\
\hline AGE & $\begin{array}{l}-0.0002^{* *} \\
(0.0001)\end{array}$ & $\begin{array}{l}-0.0001 \\
(0.0001)\end{array}$ & $\begin{array}{l}-0.0002^{*} \\
(0.0001)\end{array}$ & $\begin{array}{l}-0.0001 \\
(0.0001)\end{array}$ & $\begin{array}{l}-0.0002^{*} \\
(0.0001)\end{array}$ \\
\hline GROWTH & $\begin{array}{l}0.0034 * * * \\
(0.0006)\end{array}$ & $\begin{array}{l}0.0033^{* * *} \\
(0.0006)\end{array}$ & $\begin{array}{l}0.0031 * * * \\
(0.0006)\end{array}$ & $\begin{array}{l}0.0032^{* * *} \\
(0.0006)\end{array}$ & $\begin{array}{l}0.0033^{* * *} \\
(0.0006)\end{array}$ \\
\hline POWER & & $\begin{array}{l}0.0358^{* *} \\
(0.0177)\end{array}$ & $\begin{array}{l}-0.0544 * * * \\
(0.0209)\end{array}$ & $\begin{array}{l}0.0141^{* *} \\
(0.0068)\end{array}$ & $\begin{array}{c}0.0357 \\
(0.0240)\end{array}$ \\
\hline$D_{\text {chinese }} \times$ POWER & & $\begin{array}{l}-0.0153 \\
(0.0216)\end{array}$ & $\begin{array}{l}0.0593^{* *} \\
(0.0256)\end{array}$ & $\begin{array}{l}-0.0258^{* * *} \\
(0.0096)\end{array}$ & $\begin{array}{l}-0.0378 \\
(0.0255)\end{array}$ \\
\hline Year effect & Yes & Yes & Yes & Yes & Yes \\
\hline Sector effect & Yes & Yes & Yes & Yes & Yes \\
\hline $\bar{N}$ & 2171 & 2171 & 2171 & 2171 & 2171 \\
\hline Lambda & $\begin{array}{c}0.0053 \\
(0.0618)\end{array}$ & & & & \\
\hline$A R(1)$ & $\begin{array}{l}-4.9195 * * * \\
{[0.0000]}\end{array}$ & $\begin{array}{l}-4.8741 * * * \\
{[0.0000]}\end{array}$ & $\begin{array}{l}-4.9073^{* * *} \\
{[0.0000]}\end{array}$ & $\begin{array}{l}-4.8951 * * * \\
{[0.0000]}\end{array}$ & $\begin{array}{l}-4.9370^{* * *} \\
{[0.0000]}\end{array}$ \\
\hline$A R(2)$ & $\begin{array}{l}-0.7933 \\
{[0.4276]}\end{array}$ & $\begin{array}{l}-0.8967 \\
{[0.3699]}\end{array}$ & $\begin{array}{l}-0.6858 \\
{[0.4928]}\end{array}$ & $\begin{array}{l}-0.8338 \\
{[0.4044]}\end{array}$ & $\begin{array}{l}-0.8156 \\
{[0.4147]}\end{array}$ \\
\hline Hansen & $\begin{array}{l}78.9125 \\
{[0.9731]}\end{array}$ & $\begin{array}{l}76.9242 \\
{[0.9744]}\end{array}$ & $\begin{array}{c}76.5925 \\
{[0.9761]}\end{array}$ & $\begin{array}{c}78.2342 \\
{[0.9613]}\end{array}$ & $\begin{array}{l}79.8494 \\
{[0.9559]}\end{array}$ \\
\hline
\end{tabular}

Note: CAPEX is the proxy of risk taking (RISK) which is measured by capital expenditure divided by book value of total assets. The control variables include PERFORMANCE (measured by net income divided by total assets), SIZE (measured by natural logarithm of total assets), VALUE (measured by Tobin's $Q$, the market value of all outstanding shares and the firm's debts, divided by book value of total assets), AGE (measured by number of years since the firm is incorporated), and GROWTH (measured by net sales of current year minus net sales of previous year divided by net sales of previous year). The main independent variable is $D_{\text {chinese }}$ which is a dummy variable taking a value of 1 if the CEO is Malaysian Chinese, and zero otherwise. POWER-S, POWER-O, POWER-E, and POWER-P represent CEO duality, share ownership, CEO with foreign working experience, and founder CEO, respectively. $\mathrm{N}$ is the number of firm-year observations. $A R(1)$ and $A R(2)$ are diagnostic tests on first order and second order autocorrelation of the residual, respectively, whereas Hansen is the Hansen test of over-identification on the instrumental variables. Figures in parentheses (...) and [...] are standard errors and $p$-value, respectively. $* * *, * *, *$ denote statistical significance at $1 \%, 5 \%$ and $10 \%$ respectively. 
as explained by Lewellyn and Muller-Kahle (2012) and Ho et al. (2016). On the other hand, the significant negative interaction of CEO foreign working experience shows that greater expert power CEOs tend to portray lower risk taking behaviour. The reason could be that the CEOs' working experience in foreign countries have given them broader exposure on risk management and as a result, they are more cautious before engaging in unnecessary risk taking. Obviously, the above results on CEO power are mixed, unlike previous literature such as Pathan (2009) and Haider and Fang (2018) who found that more powerful CEOs are less willing to take risk.

\subsection{Internal Monitoring (Independent Directors)}

The ratio of independent directors is an important internal control mechanism because they are not affiliated with the firms. Here, we examine whether risk taking of Malaysian Chinese CEOs would change following different types of CEO power, with and without strong independent directors. For this purpose, we segregate the sample into two, i.e. family firms with more than $40 \%$ of independent directors in the board and family firms with less than $40 \%$ of independent directors in the board. The estimated results are reported in Table 4. Comparing the results for the two subsamples, we find that first, the interaction on ownership power $\left(D_{\text {chinese }} \times\right.$ POWER-O) turns from significantly positive to insignificant when the proportion of independent directors gets into the $40 \%$ and above level. Second, on the contrary, structural power on CEO duality $\left(D_{\text {chinese }} \times\right.$ POWER-S) turns from insignificant to significantly negative when independent directors proportion is equal or higher than $40 \%$. Third, the prestige power on founderCEO ( $D_{\text {chinese }} x$ POWER-P), and expert power - foreign working experience $\left(D_{\text {chinese }} x\right.$ POWER-E) turns from significantly positive to significantly negative when independent directors proportion crosses over the $40 \%$ level. These results imply that Chinese CEOs with higher ownership power are likely to take higher risks in the absence of strong internal monitoring, but when the board is dominated by independent directors, they become risk neutral. On the contrary, the Chinese CEO with structural power is less likely to take risk with greater extent of internal monitoring. In fact, they become risk adverse. The expert power and prestige power turns from a significant positive effect to a significant negative effect when internal monitoring is more stringent. This implies that founder CEO and CEO with foreign working experience take higher risks compared to their counterparts, and when more independent directors are on the board, they become risk adverse in response to internal monitoring. In sum, the results, in a way, provide support for $\mathrm{H}_{3}$, where a higher proportion of independent directors to some extent has limited the CEO's risk taking behaviour.

\subsection{External Monitoring (Foreign Institutional Shareholdings)}

For this section, we segregate our sample into two subsamples, i.e. family firms with more than $5 \%$ of shares owned by foreign institutions and those with less than $5 \%$ of shares owned by foreign institutions. The estimated results in Table 5 shows that the Malaysian Chinese CEO dummy variable is also positive and statistically significant for the baseline and for CEO power measures for both subsamples. Comparing the 


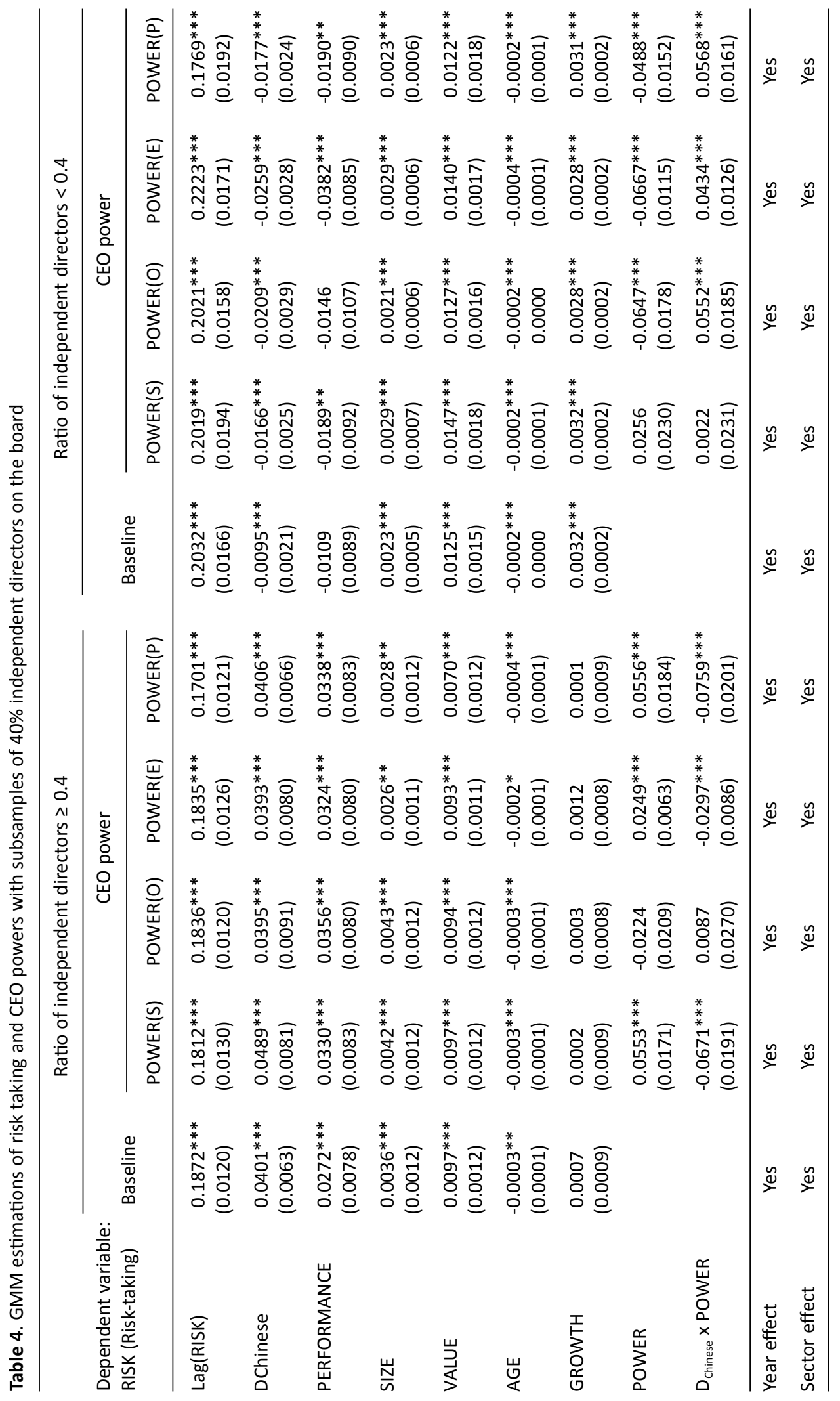




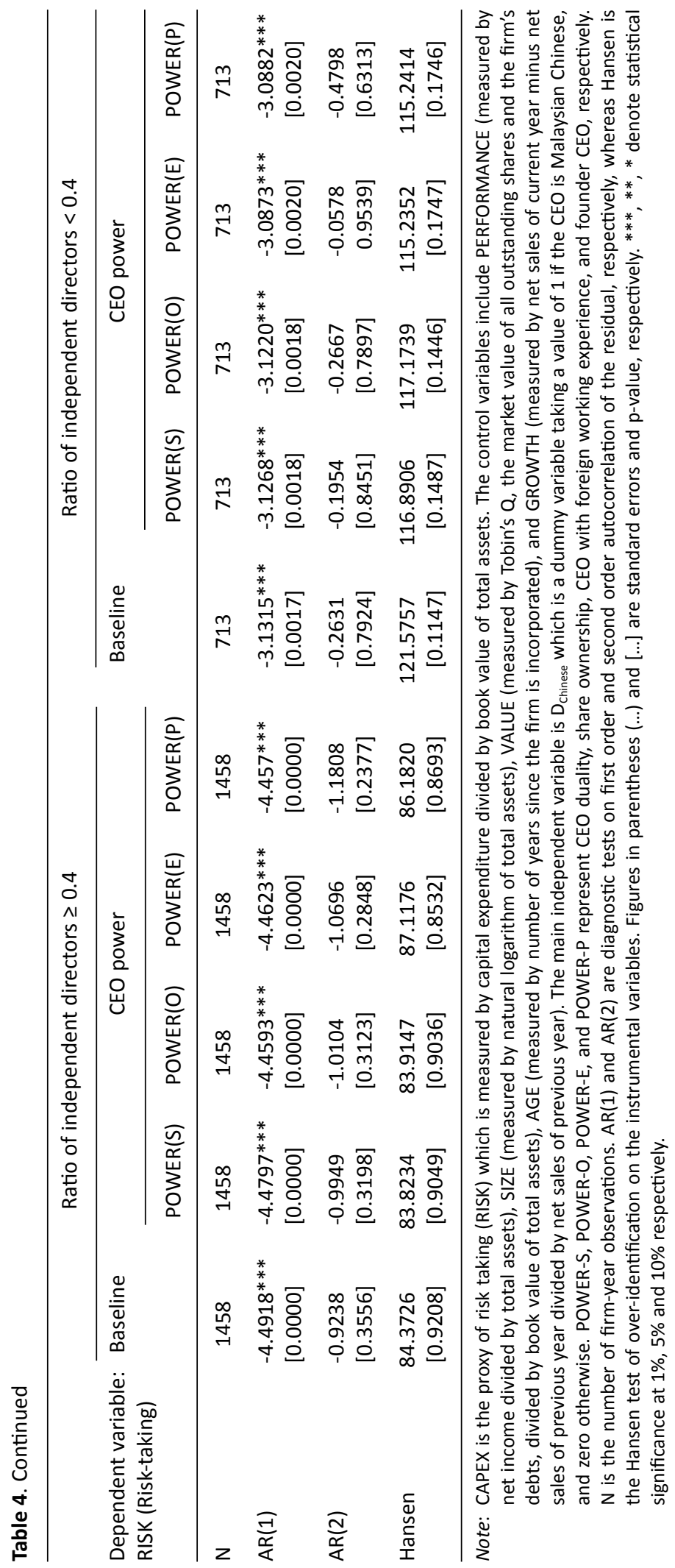




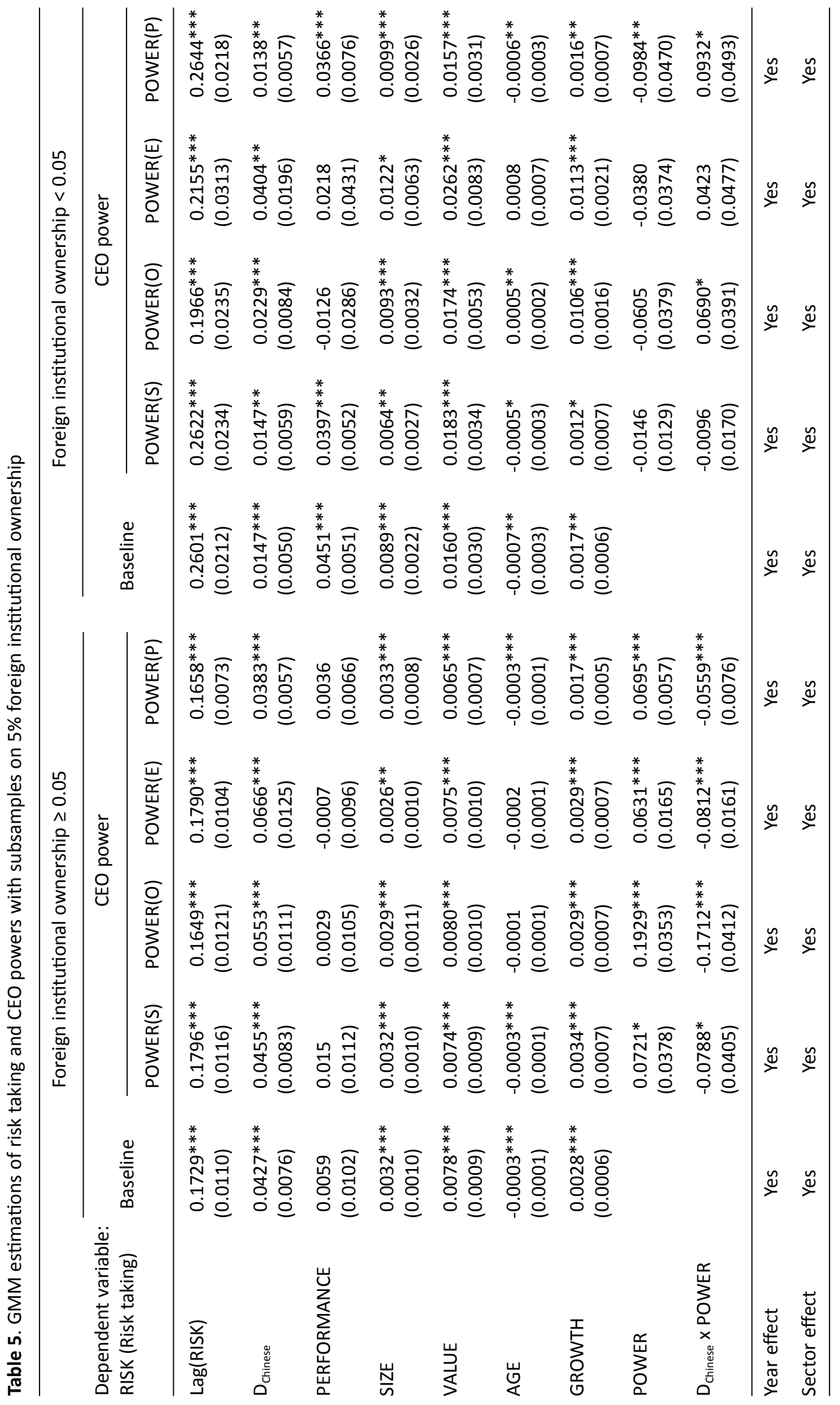




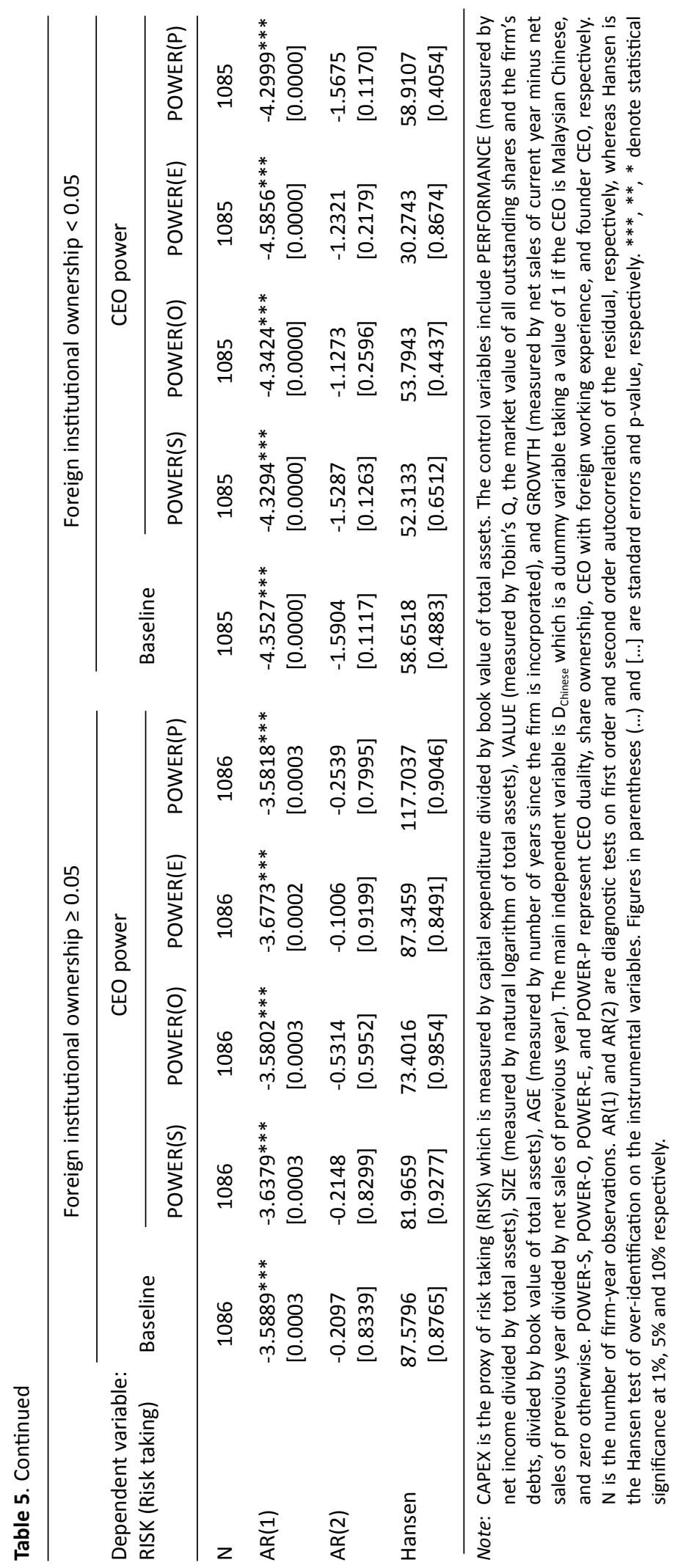


subsamples, a few observations can be summarised. First, the interaction of the Chinese dummy on all CEO powers is significantly negative when foreign institutional shareholdings is higher than $5 \%$. Second, the interaction on ownership power $\left(D_{\text {chinese }} X\right.$ POWER-O) and interaction on prestige power $\left(D_{\text {chinese }} \times\right.$ POWER-P) turn from significantly positive to significantly negative when foreign institutional shareholdings is higher than $5 \%$. The results imply that first, despite the power possessed by the Chinese CEO in family firms, the Chinese CEO tends to avoid risk when external monitoring becomes more stringent. This finding is in conformity with Tee et al. (2018) that foreign institutional investors in Malaysia are associated with a better monitoring system. As a result, Chinese CEOs are precautious in risk taking despite the power they hold. In addition, Chinese CEOs with ownership power and prestige power are taking relatively higher risk when the firm has low foreign institutional shareholdings. On the other hand, Chinese CEOs are risk averse when the firm has high foreign institutional shareholdings. This scenario could probably be explained by the latest study by Yeoh and Hooy (2020) that claimed that a founder CEO (also the owner) in an established Malaysian family firm is willing to take high risk to build his/her family businesses for the sake of his/her successor. However, when high foreign institutional shareholdings exist in the firm, the founder CEO or CEO with high ownership tend to be risk-averse. This again, conforms with the notion from past literature that external monitoring contributes to effective monitoring. In short, all the four power measures show a consistent result that supports $\mathrm{H}_{4}$.

\subsection{Robustness Test with Different Thresholds for Subsamples}

This section reports the robustness test based on different threshold values for dividing the subsamples. To conserve space, we skip the constant, lagged and controlled variables as the estimates are more or less the same with the main results. We increase the ratio of independent directors to the 75 th percentile, from $40 \%$ to $50 \%$. As shown in Table 6, we find that the results are consistent except for the interaction on expert power (DChinese x POWER-E) which remain significantly negative on both subsamples. Nevertheless, the overall results still support $\mathrm{H}_{3}$. We also increase the threshold of foreign institutional ownership to the 75th percentile, from $5 \%$ to $15 \%$. Again, the results are consistent. With strong external monitoring from foreign institutional ownership, three out of the four powers becomes negative and significant, with the exception of the prestige power. This implies that Malaysian Chinese CEOs will take higher risks when they possess higher structural power and ownership power. In fact, with a higher threshold of foreign institutional shareholdings, we detect stronger monitoring effect to support $\mathrm{H}_{4}$.

\subsection{Robustness Test with Different Proxy of Risk Taking}

As a robustness test, we change the proxy of risk taking to leverage ratio, which is measured by the ratio of total debts divided by total assets, and repeated all the estimations from Table 3 to Table 6 . The abbreviated summary results are reported in different panels in Table 7. In Panel $A$, the dummy $D_{\text {chinese }}$ is again positive and 
statistically significant for all the models which support $\mathrm{H}_{1}$. On the interaction results in Panel $A$, only CEO foreign working experience shows the same negative sign and significant interaction effect. Nonetheless, unlike the results in Table 3, CEO share ownership in Table 7 shows insignificant effects. Generally, $\mathrm{H}_{2}$ is still supported. For $\mathrm{H}_{3}$ and $\mathrm{H}_{4}$, the results in Panel $B$, Panel $\mathrm{C}$ and Panel $\mathrm{D}$ are also consistent with those in Table 4, Table 5 and Table 6, supporting the notion that for family firms under stringent internal and external monitoring, Chinese CEOs with power tend to avoid risk, and with stricter internal and external monitoring, they become even more risk averse.

\section{Conclusion}

There is a lack of empirical evidence on Chinese CEO and their managerial risk taking behaviour. This study examines whether the Malaysian Chinese CEO in listed family firms has higher risk taking appetite relative to CEOs of other ethnicity. Using the Malaysian sample, this study contributes solid comparative evidence in showing that overseas Chinese engage in more risk taking than other ethnicity in a multiracial society. Following standard family firm criteria, we obtained 362 family firms with 2534 firmyear observations from 2009 to 2015 period. Our modelling is based on dynamic panel regressions that can address the endogeneity issues.

We documented three important findings. Firstly, we show that Chinese CEOs in family firms take significantly higher risk. We then examine how CEO power, in the context of Finkelstein's (1992) structural power, ownership power, expert power and prestige power might drive risk taking of the Chinese CEO. The results are rather mixed where greater ownership power is likely to promote more risk taking but greater expert power resulted in less risk taking. We further show that corporate governance mitigates risk taking of the Chinese CEO. Using the median (40\%) of the proportion of independent directors as a criterion to divide subsamples, we find that internal monitoring, to some extent, can limit the CEO's risk taking behaviour. While using the median (5\%) of foreign institutional shareholdings to divide subsamples, we also find that CEO power lead to less risk taking except for prestige power. The evidence is even stronger when the 75th percentile thresholds are used to divide the subsamples, i.e., $50 \%$ and $15 \%$ in the robustness test. In general, high corporate governance mitigates risk taking of Chinese CEOs in family firms.

This study is not without its limitation. Firstly, as our focus is on family firms, we do not include non-family firms in our sample as most of the Malaysian non-family firms are predominantly controlled or influenced by government-linked investment companies (GLICS), so much so that it makes the issue of comparative study on ethnicity more complicated. Secondly, our study does not differentiate family CEOs from nonfamily (professional) CEOs as we are focusing on the Chinese CEO instead of Chinese family CEO. This issue is also interesting, but it will open more issues beyond the capacity of this paper. We leave this issue for future research. Finally, our measurement on CEO power is limited to one proxy for each dimension, so is the internal and external monitoring mechanism. Future studies could expand the robustness checking using more proxies. Also, more robustness tests with other risk measures can be conducted using other managerial risk taking proxies suggested by Hoskisson et al. (2017). 


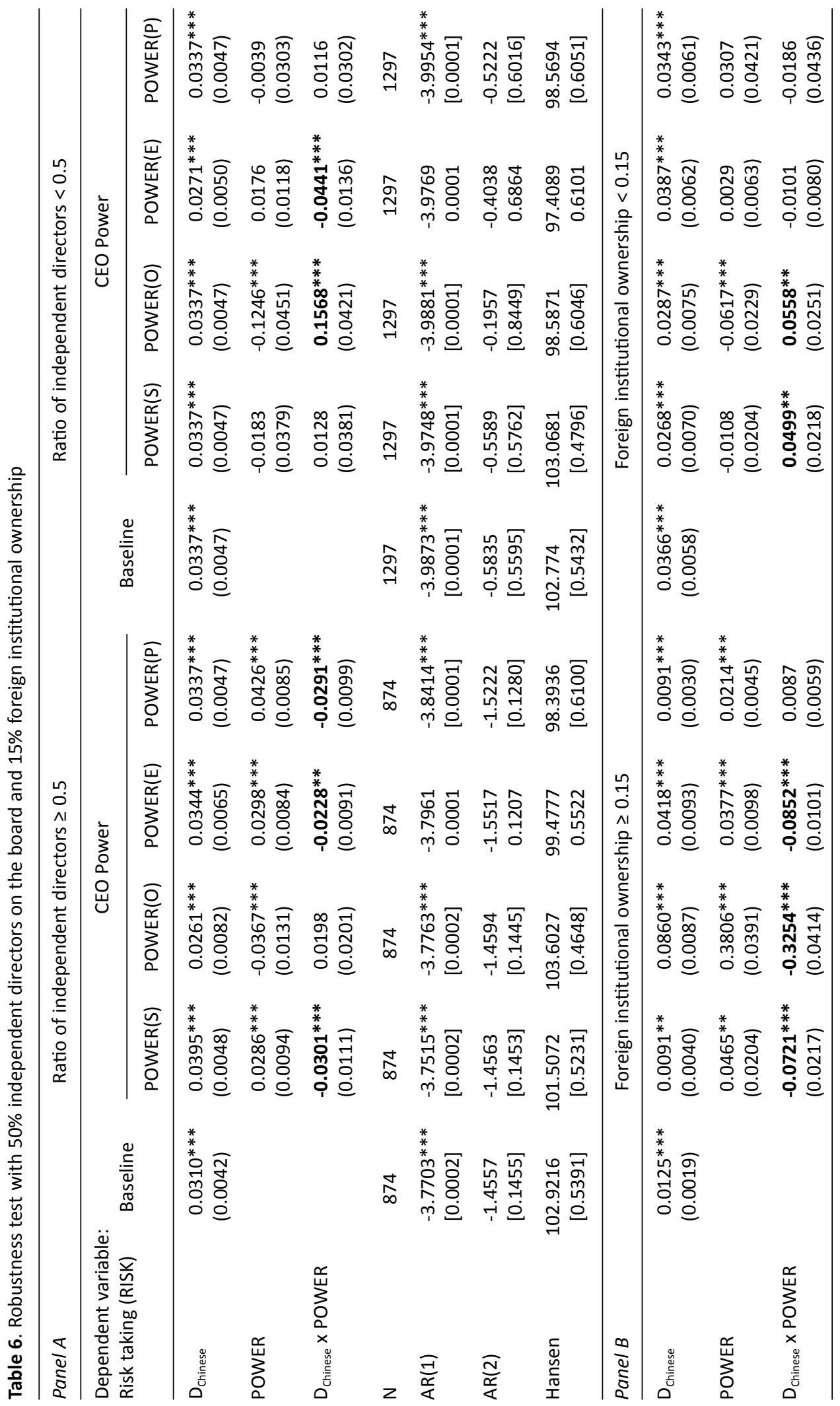




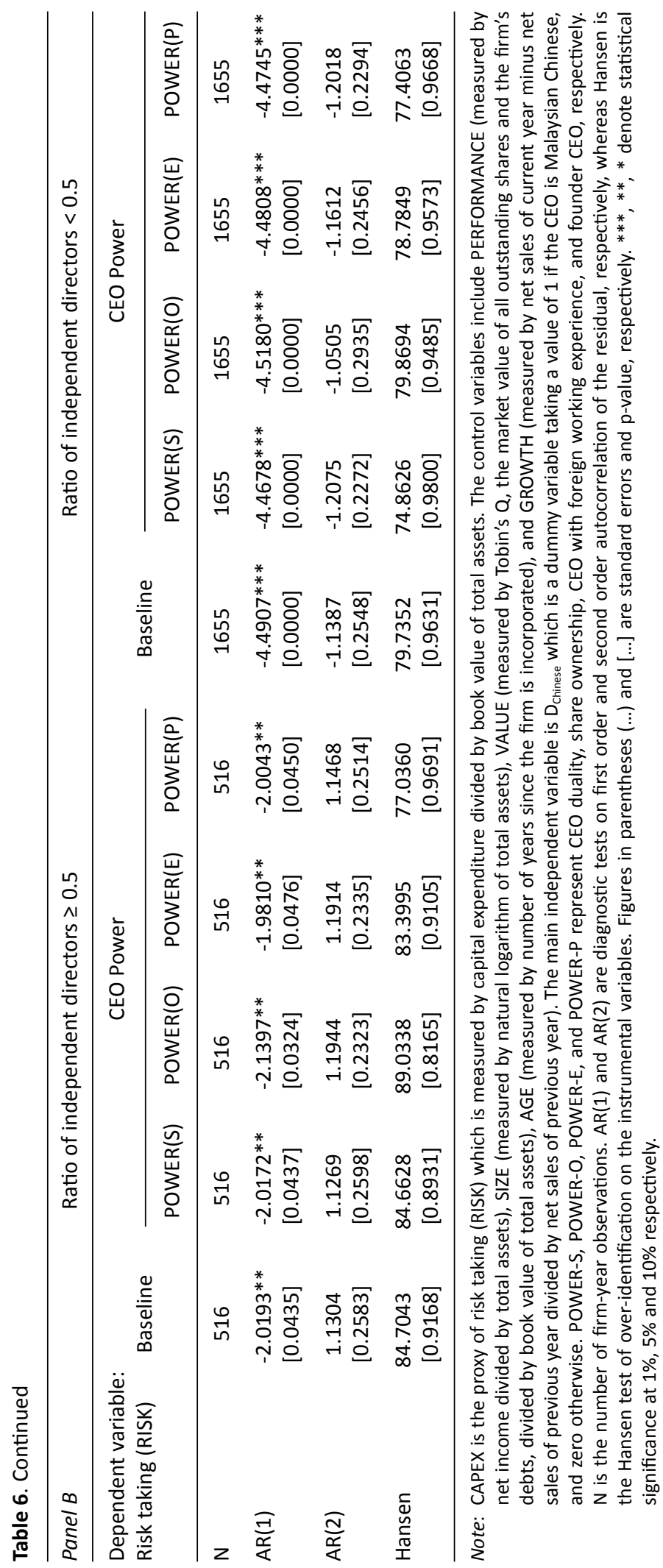




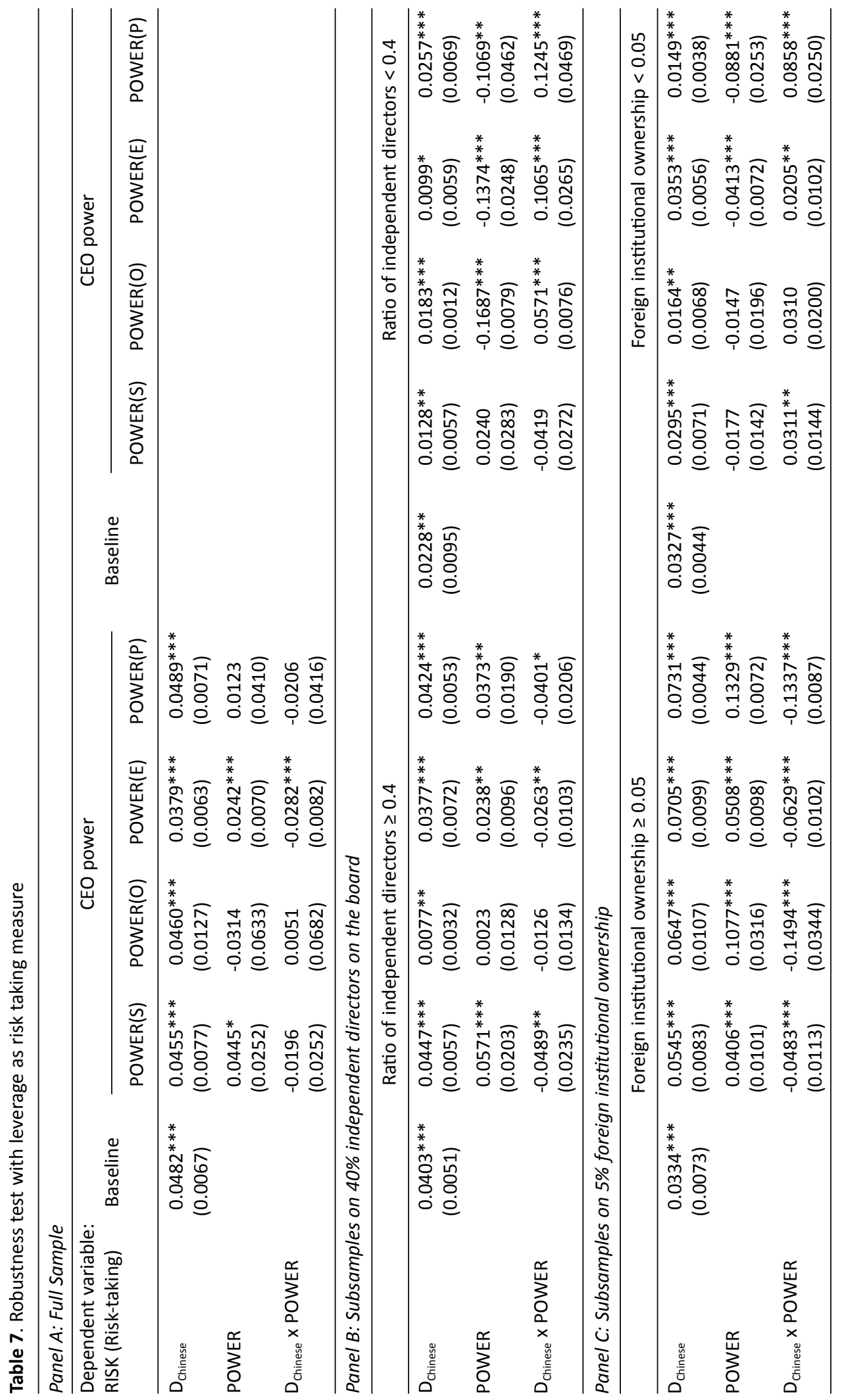




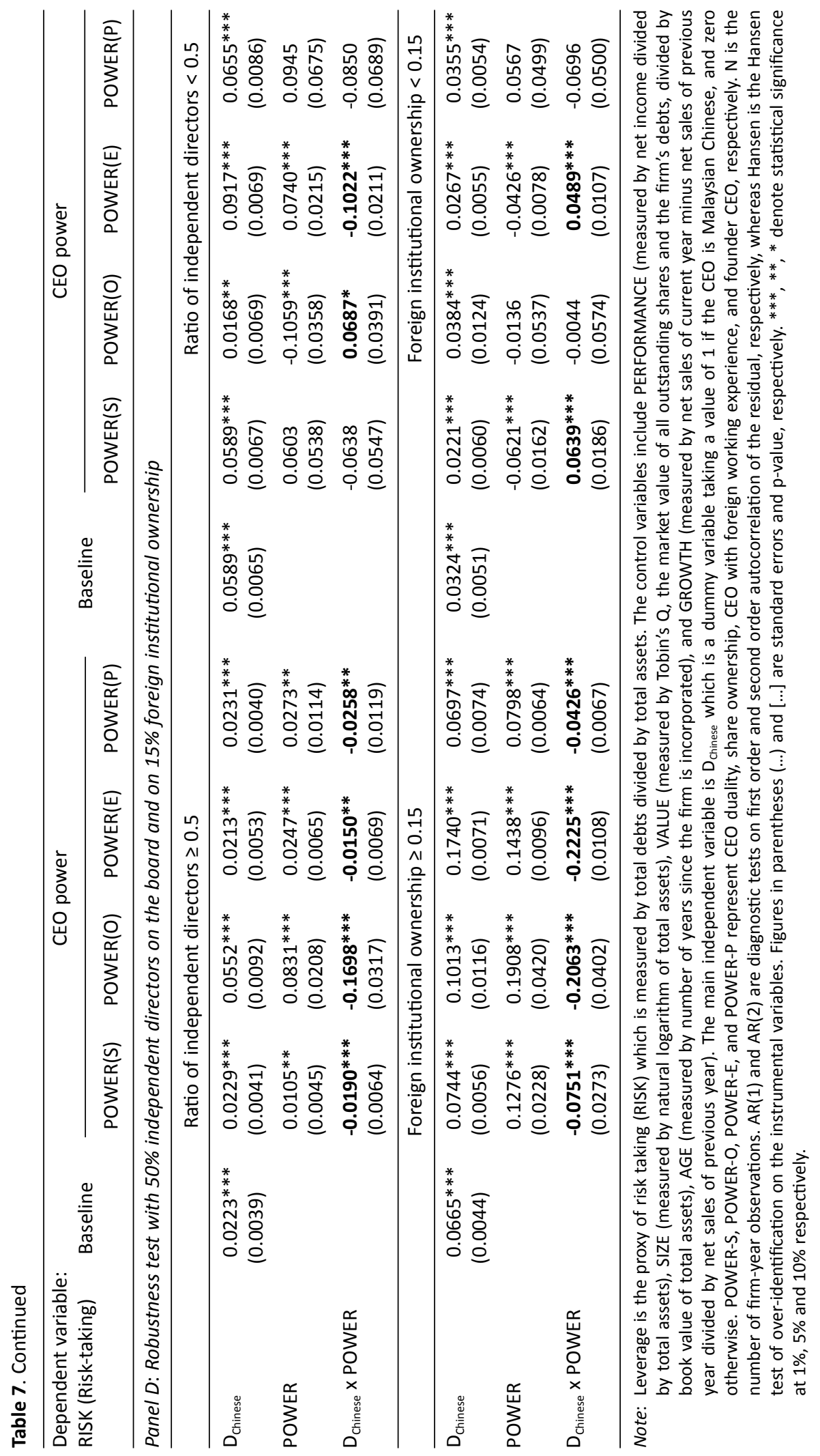




\section{References}

Abdul Samad, M.F., Amir, A., \& Ibrahim, H. (2008). Board structure and corporate performance: Evidence from public-listed family-ownership in Malaysia. https://doi.org/10.2139/ssrn. 1292182

Adhikari, B.K., \& Agrawal, A. (2016). Does local religiosity matter for bank risk-taking? Journal of Corporate Finance, 38(June), 272-293. https://doi.org/10.1016/j.jcorpfin.2016.01.009

Almazan, A., Hartzell, J.C., \& Starks, L.T. (2005). Active institutional shareholders and costs of monitoring: Evidence from executive compensation. Financial Management, 34(4), 5-34. https://doi.org/10.1111/j.1755-053X.2005.tb00116.x

Anderson, R.C., \& Reeb, D.M. (2003). Founding-family ownership and firm performance: Evidence from the S\&P 500. Journal of Finance, 58(3), 1301-1328. https://doi.org/10.1111/15406261.00567

Backman, M. (1995). Overseas Chinese business networks in Asia. East Asia Analytical Unit, Australian Department of Foreign Affairs and Trade.

Bhagat, S., \& Welch, I. (1995). Corporate research \& development investments international comparisons. Journal of Accounting and Economics, 19(2-3), 443-470. https://doi.org/10.1016/ 0165-4101(94)00391-H

Carney, R.W., \& Child, T.B. (2013). Changes to the ownership and control of East Asian corporations between 1996 and 2008: The primacy of politics. Journal of Financial Economics, 107(2), 494-513. https://doi.org/10.1016/j.jfineco.2012.08.013

Chen, M-J. (2001). Inside Chinese business: A guide for managers worldwide. Harvard Business Review Press.

Cheng, S. (2004). R\&D expenditures and CEO compensation. The Accounting Review, 79(2), 305328. https://doi.org/10.2308/accr.2004.79.2.305

Chintrakarn, P., Jiraporn, P., \& Tong, S. (2015). How do powerful CEOs view corporate risk-taking? Evidence from the CEO pay slice (CPS). Applied Economics Letters, 22(2), 104-109. https:// doi.org/10.1080/13504851.2014.927565

Cho, S.Y., \& Kim, S.K. (2017). Horizon problem and firm innovation: The influence of CEO career horizon, exploitation and exploration on breakthrough innovations. Research Policy, 46(10), 1801-1809. https://doi.org/10.1016/j.respol.2017.08.007

Chuah, S.H., Hoffmann, R., Ramasamy, B., \& Tan, J.H.W. (2016). Is there a spirit of overseas Chinese capitalism? Small Business Economics, 47(4), 1095-1118. https://doi.org/10.1007/ s11187-016-9746-5

Claessens, S., Djankov, S., \& Lang, L.H.P. (2000). The separation of ownership and control in East Asian corporations. Journal of Financial Economics, 58(1-2), 81-112. https://doi.org/10.1016/ S0304-405X(00)00067-2

Coles, J.L., Daniel, N.D., \& Naveen, L. (2006). Managerial incentives and risk-taking. Journal of Financial Economics, 79(2), 431-468. https://doi.org/10.1016/j.jfineco.2004.09.004

Credit Suisse. (2018). The CS Family 1000 in 2018. file:///C:/Users/User/Downloads/the-cs-family1000-in-2018.pdf

Daily, C.M., Johnson, J.L., Ellstrand, A.E., \& Dalton, D.R. (1998). Compensation committee composition as a determinant of CEO compensation. Academy of Management Journal, 41(2), 209-220. https://doi.org/10.5465/257103

Del Guercio, D., \& Hawkins, J. (1999). The motivation and impact of pension fund activism. Journal of Financial Economics, 52(3), 293-340. https://doi.org/10.1016/S0304-405X(99) 00011-2

Dimson, E., Karakaş, O., \& Li, X. (2015). Active ownership. Review of Financial Studies, 28(12), 3225-3268. https://doi.org/10.1093/rfs/hhv044

Elyasiani, E., \& Jia, J.J. (2008). Institutional ownership stability and BHC performance. Journal of Banking \& Finance, 32(9), 1767-1781. https://doi.org/10.1016/j.jbankfin.2007.12.010 
Fan, J.P.H., Wei, K.C.J., \& Xu, X. (2011). Corporate finance and governance in emerging markets: A selective review and an agenda for future research. Journal of Corporate Finance, 17(2), 207214. https://doi.org/10.1016/j.jcorpfin.2010.12.001

Finkelstein, S. (1992). Power in top management teams: Dimensions, measurement, and validation. Academy of Management Journal, 35(3), 505-538. https://doi.org/10.5465/256485

Gomez-Mejia, L.R., Nunez-Nickel, M., \& Gutierrez, I. (2001). The role of family ties in agency contracts. Academy of Management Journal, 44(1), 81-95. https://doi.org/10.5465/3069338

Haider, J., \& Fang, H.-X. (2018). CEO power, corporate risk taking and role of large shareholders. Journal of Financial Economic Policy, 10(1), 55-72. https://doi.org/10.1108/JFEP-04-20170033

Harjoto, M.A., Laksmana, I., \& Yang, Y.W. (2018). Board diversity and corporate risk taking. https:// doi.org/10.2139/ssrn.2412634

Ho, P-H., Huang, C-W., Lin, C-Y., \& Yen, J-F. (2016). CEO overconfidence and financial crisis: Evidence from bank lending and leverage. Journal of Financial Economics, 120(1), 194-209. https://doi.org/10.1016/j.jfineco.2015.04.007

Hofstede, G. (2001). Culture's recent consequences: Using dimension scores in theory and research. International Journal of Cross Cultural Management, 1(1), 11-17. https://doi.org/ $10.1177 / 147059580111002$

Hoskisson, R.E., Chirico, F., Zyung, J. (Daniel), \& Gambeta, E. (2017). Managerial risk taking: A multitheoretical review and future research agenda. Journal of Management, 43(1), 137-169. https://doi.org/10.1177/0149206316671583

Janakiraman, S., Radhakrishnan S., \& Tsang A. (2010). Institutional investors, managerial ownership, and executive compensation. Journal of Accounting, Auditing \& Finance, 25(4), 673707. https://doi.org/10.1177/0148558X1002500409

Lewellyn, K.B., \& Muller-Kahle, M.I. (2012). CEO power and risk taking: Evidence from the subprime lending industry. Corporate Governance: An International Review, 20(3), 289-307. https://doi.org/10.1111/j.1467-8683.2011.00903.x

$\mathrm{Li}$, J., \& Tang, Y. (2010). CEO hubris and firm risk taking in China: The moderating role of managerial discretion. Academy of Management Journal, 53(1), 45-68. https://doi.org/ 10.5465/amj.2010.48036912

Mazur, M., \& Wu, B.H.T. (2016). Founding family firms, CEO incentive pay, and dual agency problems. Journal of Small Business Management, 54(4), 1099-1125. https://doi.org/ $10.1111 / \mathrm{jsbm} .12237$

Pathan, S. (2009). Strong boards, CEO power and bank risk-taking. Journal of Banking \& Finance, 33(7), 1340-1350. https://doi.org/10.1016/j.jbankfin.2009.02.001

Rodríguez-Gutiérrez, M.J., Romero, I., \& Yu, Z. (2020). Guanxi and risk-taking propensity in Chinese immigrants' businesses. International Entrepreneurship and Management Journal, 16, 305-325. https://doi.org/10.1007/s11365-019-00566-9

Rosenstein, S., \& Wyatt, J.G. (1990). Outside directors, board independence, and shareholder wealth. Journal of Financial Economics, 26(2), 175-191. https://doi.org/10.1016/0304$405 \times(90) 90002-\mathrm{H}$

Sheikh, S. (2019). CEO power and corporate risk: The impact of market competition and corporate governance. Corporate Governance: An International Review, 27(5), 358-377. https://doi. org $/ 10.1111 /$ corg. 12285

Shleifer, A., \& Vishny, R.W. (1997). A survey of corporate governance. The Journal of Finance, 52(2), 737-783. https://doi.org/10.1111/j.1540-6261.1997.tb04820.x

Soto, M. (2009). System GMM estimation with a small sample. (Working Paper 395). Barcelona Graduate School of Economics.

Stapledon, G.P. (1996). Institutional shareholders and corporate governance. Clarendon Press. 
Statista. (2018). Countries with the largest number of overseas Chinese. Retrieved September 27, 2018, from https://www.statista.com/statistics/279530/countries-with-the-largest-numberof-overseas-chinese/

Tee, C.M., Foo, Y-B., Gul, F.A., \& Majid, A. (2018). Institutional investors and CEO pay performance in Malaysian firms. Journal of International Accounting Research, 17(1), 87-102. https://doi. org/10.2308/jiar-51989

Villalonga, B., \& Amit, R. (2006). How do family ownership, control and management affect firm value? Journal of Financial Economics, 80(2), 385-417. https://doi.org/10.1016/j.jfineco. 2004.12.005

Wintoki, M.B., Linck, J.S. and Netter, J.M. (2012). Endogeneity and the dynamics of internal corporate governance. Journal of Financial Economics, 105(3), 581-606. https://doi.org/ 10.1016/j.jfineco.2012.03.005

Yeoh, S-B., \& Hooy, C-W. (2020). CEO age and risk-taking of family business in Malaysia: The inverse S-curve relationship. Asia Pacific Journal of Management, 1-21. https://doi. org/10.1007/s10490-020-09725-x

Yeung, H.W.C. (1996). Business networks and transnational corporations: A study of Hong Kong firms in the ASEAN region. Economic Geography, 73(1), 1-25. https://doi.org/10.1111/ j.1944-8287.1997.tb00082.x

Zhang, C., \& Fu, P. (2020). Overseas-returned executives and their roles in firm performance: Evidence from China. Asia-Pacific Journal of Accounting \& Economics, 1-10. https://doi.org/ 10.1080/16081625.2020.1754257

Zheng, Y. (2010). Heterogeneous institutional investors and CEO compensation. Review of Quantitative Finance and Accounting, 35(1), 21-46. https://doi.org/10.1007/s11156-009-0142-y 